\title{
Higher-Order Thinking Skill (HOTS) Instrument-Based Cognitive Evaluation in Grade V Elementary School Students
}

\section{Sang Ayu Diah Febrianti1 ${ }^{*}$, I Wayan Widiana ${ }^{2}$, Kadek Yudiana ${ }^{3}$}

1,2,3 Primary Education Department, Ganesha University of Education, Singaraja, Indonesia

\section{ART ICLE IN F O}

Article history:

Received August 16, 2021

Revised Auguts 17, 202

Accepted September 30, 2021

Available online October 25, 2021

Kata Kunci:

Higher-Order Thinking Skill

(HOTS), Evaluasi Kognitif

Keywords:

Higher-Order Thinking Skill

(HOTS), Cognitive Evaluation

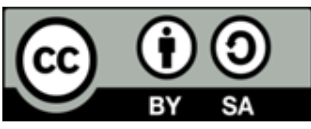

This is an open access article under the CC BY-SA license.

Copyright (C) 2021 by Author. Published by Universitas Pendidikan Ganesha.

\begin{abstract}
A B S T RAK
Rendahnya kemampuan berpikir siswa disebabkan oleh kurangnya pengimplementasian pembelajaran berbasis HOTS. Guru belum pernah melakukan analisis butir soal seperti analisis distraktor, daya pembeda, maupun tingkat kemudahan soal. Penelitian ini bertujuan mendeskripsikan tahap pengembangan instrumen kemampuan HOTS, menghitung validitas, reliabilitas, tingkat kesukaran, daya beda, dan efektifitas pengecoh untuk mengetahui kelayakan dari instrumen. Jenis penelitian ini adalah penelitian pengembangan dengan tahapan meliputi pendahuluan, pengembangan, validasi, uji coba lapangan, dan revisi. Subjek penelitian ini terdiri dari 4 pakar dan 26 siswa kelas V SD. Metode yang digunakan untuk mengumpulkan data adalah metode tes dengan instumen pilihan ganda. Analisis data yang digunakan yaitu analisis validitas reliabilitas tingkat kesukaran, daya beda dan efektifitas pengecoh. Hasil penelitian menunjukkan instrumen kemampuan HOTS sebanyak 30 butir soal teruji kualitasnya memiliki kualitas validitas isi dengan hasil 1, 00 (sangat tinggi), kualitas validitas butir soal dengan hasil semua soal valid, kualitas reliabilitas butir soal dengan hasil sebesar 0,913,memiliki kualitas tingkat kesukaran dengan hasil 7 soal termasuk kategori mudah, 21 soal termasuk kategori sedang dan 2 soal termasuk kategori sukar, kualitas daya beda lebih dari 0,40, danefektifitas pengecoh diperoleh setiap butir soal tergolong baik. Dapat disimpulkan bahwa instrumen kemampuan HOTS yang dikembangkan memiliki kualitas yang baik dan layak digunakan sebagai penilaian pembelajaran pada aspek kognitif siswa.
\end{abstract}

\begin{abstract}
A B S T R A C T
The low thinking ability of students is caused by the lack of implementation of HOTS-based learning. The teacher has never done item analysis such as distractor analysis, discriminatory power, or the level of ease of questions. This study aims to describe the stage of developing the HOTS capability instrument, calculating validity, reliability, difficulty level, discriminating power, and distractor effectiveness to determine the feasibility of the instrument. This type of research is developed with stages including introduction, development, validation, field trials, and revisions. This study consisted of 4 experts and 26 fifth-grade elementary school students. The method used to collect data is a test method with multiple-choice instruments. The data analysis was used to analyze the reliability of the difficulty level, discriminating power, and the distractor's effectiveness. The results showed the HOTS ability instrument as many as 30 items tested the quality has the quality of content validity with a result of 1.00 (very high), the quality of item validity with the results of all valid questions, the quality of the reliability of the items with a result of 0.913 , has a quality level of difficulty with The results of 7 questions are included in the easy category, 21 questions are included in the medium category, and two questions are included in the difficult category, the quality of discriminating power is more than 0.40 , and the effectiveness of distractors is obtained for each item classified as good. It can be concluded that the developed HOTS ability instrument has good quality and is suitable for use as an assessment of learning on students' cognitive aspects.
\end{abstract}

\section{INTRODUCTION}

Advances in science and technology have had a profound impact on life. Of course, to compete and survive amid the onslaught of technological developments, the educational outcome must also be improved. 
Therefore, the government requires that the current education process focuses on high-level thinking skills. High Order Thinking Skill (HOTS) is a high-level thinking skill that requires critical and analytical thinking about a phenomenon or information in solving a problem. Higher-Order Thinking Skills (HOTS) are highlevel thinking skills ranging from evaluating ideas to decision making (Prayitno, 2018). HOTS in Bloom's taxonomy deals with the ability to solve problems, think critically and think creatively. In other words, HOTS can be categorized as analysis, evaluation, and creation (Sani, 2016). HOTS is very important to be mastered in the $21^{\text {st }}$-century era. Facing the 21st century, it takes a creative human being to think critically and skillfully solve problems. These skills can be achieved if the teacher transforms his learning from more LOTS to more HOTS. Improving the ability to think high can be done by using the right learning model, and HOTS training problems can improve the ability of students' HOTS (Arifin \& Retnawati, 2017). So, it can be said that to develop high-level thinking skills, students need an innovative learning model and great research. Assessment is one of the ways used to find out the success of the learning process (Tridane et al., 2015). The learning assessment will provide students with the agreement to improve and develop their abilities in the learning process (Xiao \&Yang, 2019). The assessment process should be done daily to make changes during the learning. With the assessment process, the student's ability will be known, such as students' knowledge, attitude, and skills after the learning process (Schildkamp et al., 2020; Zhang, 2020). The assessment process provides an agreement to determine how the learning conditions are ongoing (Msosa et al., 2021). The assessment conducted by the teacher will have an impact on students because it provides feedback from what has been learned by students (Granberg et al., 2021). Based on this, the research process must have a certain quality. Reminding that the assessment is one factor that determines the success of the learning process. Improving the quality of learning can be achieved through improving the quality of learning and the quality of its assessment system (Ndiung \& Jediut, 2020; Sugian, 2020).

However, based on the results of observations, teachers cannot develop HOTS assessment instruments, even though this assessment instrument is a very important aspect to be developed following the implementation of the 2013 curriculum. The teacher has never analyzed problem items such as the analysis of the distractor, the discrimination power, or the level of ease of the problem. During the midterm assessment, on the question of multiple choices that have been prepared, the teacher did not pay attention to the level of the distractor on the problem and the relationship between the existing concepts. In addition, the questions given to students are still at the level of $\mathrm{C} 1, \mathrm{C} 2$, and $\mathrm{C} 3$. The problems compiled by the teacher have not led to the cognitive domain levels C4 (analyze), C5 (evaluating), and C6 (creating). In addition, from the current situation and conditions, the covid 19 pandemic causes the learning system to occur online. Therefore, the learning method is only in assignments in student books. Most teachers sometimes did not do daily examinations. Teachers look for daily examination grades through daily tasks given to students. Meanwhile, the midterm and end of the semester are still carried out. Thus, the assessment of student learning outcomes cannot run optimally. Assessments made through problems in the student's book seem very limited and only test memorization. It does not test in analysis, synthesis, or evaluation aspects. This can lead to a lack of students' ability to think at a high level. Low ability to think high levels of students due to the lack of availability of test questions specifically designed to train the use of high-level thinking in solving contextual problems, reasoning, argumentation, and creativity (Noprinda \& Soleh, 2019; Cayani et al., 2021). If this is allowed, it will impact how the learning process continues in the future. Therefore, it is considered necessary to do a solution to solve the problem. The solution offered is to create a HOTs instrument.

Instruments are one of the important components in the learning process. Produce a good instrument to pay attention to the language of the instruments that developed, clear instructions, and cognitive abilities that match the students' ability level. The instruments developed have a language that is communicative and easy to understand. Sentences in the instrument statement will affect the student's answer if the student does not understand the statement. It will confuse the student in filling in the answer, and they may answer statements that are not understood arbitrarily (Yugakisha \& Jayanta, 2021). Besides, instrument development needs clear steps. The development stage is the curriculum analysis stage (basic competency analysis, indicators, and materials), making the blueprint concerned with the assessment instrument and making instruments concerned with the indicators developed (Safitri \& Harjono, 2021). Besides, a good instrument qualifies for a good instrument that is valid, reliable, and practical (Solihah et al., 2020; Yusup, 2018). Thus, developing assessment instruments needs to pay attention to students' character, materials, and curriculum and meet the current demands. Some studies related to the HOTS include research that states from 12 HOTS problems made, only 4 points of questions can be used, with 2 points of problems that require improvement. Its reliability was at a high level, which is 0.74 . Meanwhile, for the quality, it was in a good category. Therefore, the four problems can be used to evaluate grade VII learners (Aviory \& Susetyawati, 2021). The study found that the test instrument to measure Higher Order Thinking Skills (HOTS) is oriented to the Programme for International Student Assessment (PISA) in 
Learners. The analysis results on this instrument obtained $50 \%$ of students and showed the category "very competent" (Umami et al., 2021). The research found that validation of the content of assessment instruments by three validators showed that 77 out of 90 conceptual understanding questions are categorized as HOTS questions with very valid criteria (90.91-100\%), 60 questions of science process skills with very valid criteria (94.70-100\%), 55 statements of attitude towards science with very valid criteria (86.67- 100\%), and performance of assessment instrument products with very valid criteria (91.67\%)(Amin et al., 2018). The research revealed that high-level thinking ability assessment instruments about digestive system materials are valid enough developed in terms of matter, construction, language as well as the cognitive level of high-level thinking ability assessment instruments so that it can be used to measure learners' high-level thinking ability about digestive system materials (Anazalia et al., 2021). Based on the results, the development of HOTS instruments has been widely done and produced an instrument used in the learning process. This study aims to describe the stage of development of HOTS instruments, calculating the validity, reliability, difficulty level, discrimination power, and effectiveness of the distractor to find out the instrument's feasibility on theme 8 (Environment of Our Friends) students of grade $\mathrm{V}$ elementary school.

\section{METHOD}

This type of research is development research. The development of HOTS instruments is carried out with 10 model stages (R \&D), namely research and information collection, planning, initial product development, expert team testing, initial revision of product test results, main field testing, revision of main field test results, operational field test, revision of operational field test products, and implementation (Amirzan, 2017). However, the research simplified the steps taken in the development of Borg and Gall into five, namely preliminary stages, development, validation, field trials, and revisions. The subjects in this study consisted of expert subjects, namely four lecturers in the Faculty of Education Undiksha and subjects for the instrument trial of 26 students of grade V elementary school in Group III Tembuku subdistrict, Bangli regency. The data collected is on higher-order thinking skills (HOTS) ability instruments. The analysis used includes the validity of the contents, the item validity test, reliability test, difficulty level test, discrimination power test, and the effectiveness of the distractor. The instrument's validity is used to determine whether it is valid or not. The instrument's validity is divided into 2, namely the content validity test, which is a technique of reviewing the instrument items whether it has represented the learning material thoroughly or otherwise has not been represented. The analysis of the content validity test uses calculations according to the CVR formula. The second item validity test determines the number of valid and invalid test items.

The correlation technique used to calculate the validity of objective test items is the point-biserial correlation technique ( $\mathrm{y}$ pbi). Reliability tests measure the consistency of a test or instrument to a subject in a study. Reliability tests are conducted after the validity test is completed. Reliability of HOTS instrument in students is using the formula KR-20 (Kuder Richardson 20) because the problem item tested is a dichotomy test item. The difficulty level of the problem item is one of the indicators that can show the quality of the problem, whether difficult, moderate, or easy. The discrimination power of the problem item, namely the problem item, can distinguish the individual learners' abilities. The differentiating power of examining the details of the problem is to find out the problem's ability to distinguish students who are classified as capable (high performance) from students who are classified as lacking (weak performance). The effectiveness of the distractor, which is one of those answer options, is the right answer, and the other is the distractor as the wrong answer option.

\section{RESULT AND DISCUSSION}

\section{Result}

The preliminary stage, conducted library research to collect data, such as conducting interviews and observations in three elementary schools, namely SD Negeri 1 Peninjoan, SD Negeri 5 Peninjoan, and SD Negeri 6 Peninjoan, to get information about instruments developed by teachers and ask for data on student learning outcomes in the second semester, conducted the curriculum analysis and student analysis. Based on curriculum analysis in elementary school, they use2013; therefore, the instrument's preparation is guided by the curriculum 2013. While the results of the student analysis are based on interviews with grade $\mathrm{V}$ teachers, the questions given to students are still at the level of $\mathrm{C} 1, \mathrm{C} 2$, and $\mathrm{C} 3$. The development stage is the second stage of this research. In the stage of preparing the blueprint following the specified basic competency, compiling instruments from the blueprint that has been compiled, making question item numbers and the number of items for each dimension and indicator, and designing answer keys, the 
questions made were 30 points of multiple-choice questions with four answer options. The blueprint of HOTS instruments is presented in Table 1.

Table 1. The blueprint of the HOTS skills instrument

\begin{tabular}{|c|c|c|c|c|c|c|}
\hline No & Basic Competency & Indicator & HOTs Aspect & Material & $\begin{array}{c}\text { Item } \\
\text { Number }\end{array}$ & $\begin{array}{c}\text { Key } \\
\text { Answer }\end{array}$ \\
\hline \multirow[t]{3}{*}{1} & $\begin{array}{l}3.8 \text { Sort the sequence } \\
\text { of events or actions in } \\
\text { nonfiction text }\end{array}$ & $\begin{array}{lr}\text { Analyze } & \text { the } \\
\text { events } & \text { or } \\
\text { actions } & \text { in } \\
\text { nonfiction } & \\
\text { text } & \end{array}$ & $\begin{array}{l}\text { Analyze (C4) } \\
\text { procedural } \\
\text { (K3) }\end{array}$ & Clean Water & 1 & B \\
\hline & & $\begin{array}{l}\text { Evaluate the } \\
\text { way to maintain } \\
\text { the clean water } \\
\text { availability }\end{array}$ & $\begin{array}{l}\text { Analyze (C4) } \\
\text { Conceptual } \\
\text { (K2) }\end{array}$ & $\begin{array}{l}\text { The benefit of clean } \\
\text { water }\end{array}$ & 2 & $\mathrm{C}$ \\
\hline & & & $\begin{array}{l}\text { Evaluate (C5) } \\
\text { Procedural } \\
\text { (K3) }\end{array}$ & $\begin{array}{l}\text { The way to } \\
\text { maintain the } \\
\text { availability of } \\
\text { clean water }\end{array}$ & 3 & A \\
\hline \multirow[t]{3}{*}{2} & $\begin{array}{l}4.8 \text { Re-presents } \\
\text { events or actions } \\
\text { with a focus on the }\end{array}$ & $\begin{array}{l}\text { Report on events } \\
\text { that occurred in } \\
\text { the fictional text }\end{array}$ & $\begin{array}{l}\text { Analyze (C4) } \\
\text { Procedural } \\
\text { (K3) }\end{array}$ & Siklus air & 4 & A \\
\hline & $\begin{array}{l}\text { background of the } \\
\text { story in the fictional } \\
\text { text }\end{array}$ & $\begin{array}{l}\text { Report on the } \\
\text { benefits of } \\
\text { water for } \\
\text { plant }\end{array}$ & $\begin{array}{l}\text { Analyze (C4) } \\
\text { Procedural } \\
\text { (K3) }\end{array}$ & $\begin{array}{l}\text { The benefits of } \\
\text { water for plant s }\end{array}$ & 5 & B \\
\hline & & $\begin{array}{l}\text { Report the } \\
\text { results of } \\
\text { observations } \\
\text { related to } \\
\text { the process } \\
\text { of } \\
\text { groundwater }\end{array}$ & $\begin{array}{l}\text { Analyze (C4) } \\
\text { Procedural } \\
\text { (K3) }\end{array}$ & Groundwater & 6 & B \\
\hline \multirow[t]{4}{*}{3} & $\begin{array}{l}\text { 3.8 Analyze the water } \\
\text { cycle and its impact on } \\
\text { events on earth as well } \\
\text { as the survival of living } \\
\text { creatures }\end{array}$ & $\begin{array}{l}\text { Analyze the } \\
\text { impact of the } \\
\text { water cycle on } \\
\text { events in } \\
\text { earth }\end{array}$ & $\begin{array}{l}\text { Analyze (C4) } \\
\text { Metacognitive } \\
\text { (K4) }\end{array}$ & $\begin{array}{l}\text { The impact of the } \\
\text { water cycle }\end{array}$ & 7 & $\mathrm{D}$ \\
\hline & & $\begin{array}{l}\text { Analyze the } \\
\text { impact of the } \\
\text { water cycle on } \\
\text { the survival of } \\
\text { living } \\
\text { creatures }\end{array}$ & Analyze (C4) & Water recycling & 8 & $\mathrm{C}$ \\
\hline & & & Conceptual (K2) & & & \\
\hline & & $\begin{array}{l}\text { Recognize } \\
\text { the process } \\
\text { that occurs } \\
\text { in the water } \\
\text { cycle. }\end{array}$ & $\begin{array}{l}\text { Analyze (C4) } \\
\text { Procedural } \\
\text { (K3) }\end{array}$ & Water cycle & 9 & B \\
\hline \multirow[t]{2}{*}{4} & $\begin{array}{l}4.8 \text { Create work on } \\
\text { information-based } \\
\text { water cycle schemes }\end{array}$ & $\begin{array}{l}\text { Make a report on } \\
\text { the water cycle } \\
\text { scheme }\end{array}$ & $\begin{array}{l}\text { Analyze (C4) } \\
\text { Procedural } \\
\text { (K3) }\end{array}$ & Water cycle & 10 & A \\
\hline & from multiple sources & $\begin{array}{l}\text { Make a report on } \\
\text { the water } \\
\text { conditions } \\
\text { scheme that is }\end{array}$ & $\begin{array}{l}\text { Evaluate (C5) } \\
\text { Metacognitive } \\
\text { (K4) }\end{array}$ & $\begin{array}{l}\text { Terms of water } \\
\text { that is worth } \\
\text { drinking }\end{array}$ & 11 & $\mathrm{C}$ \\
\hline
\end{tabular}




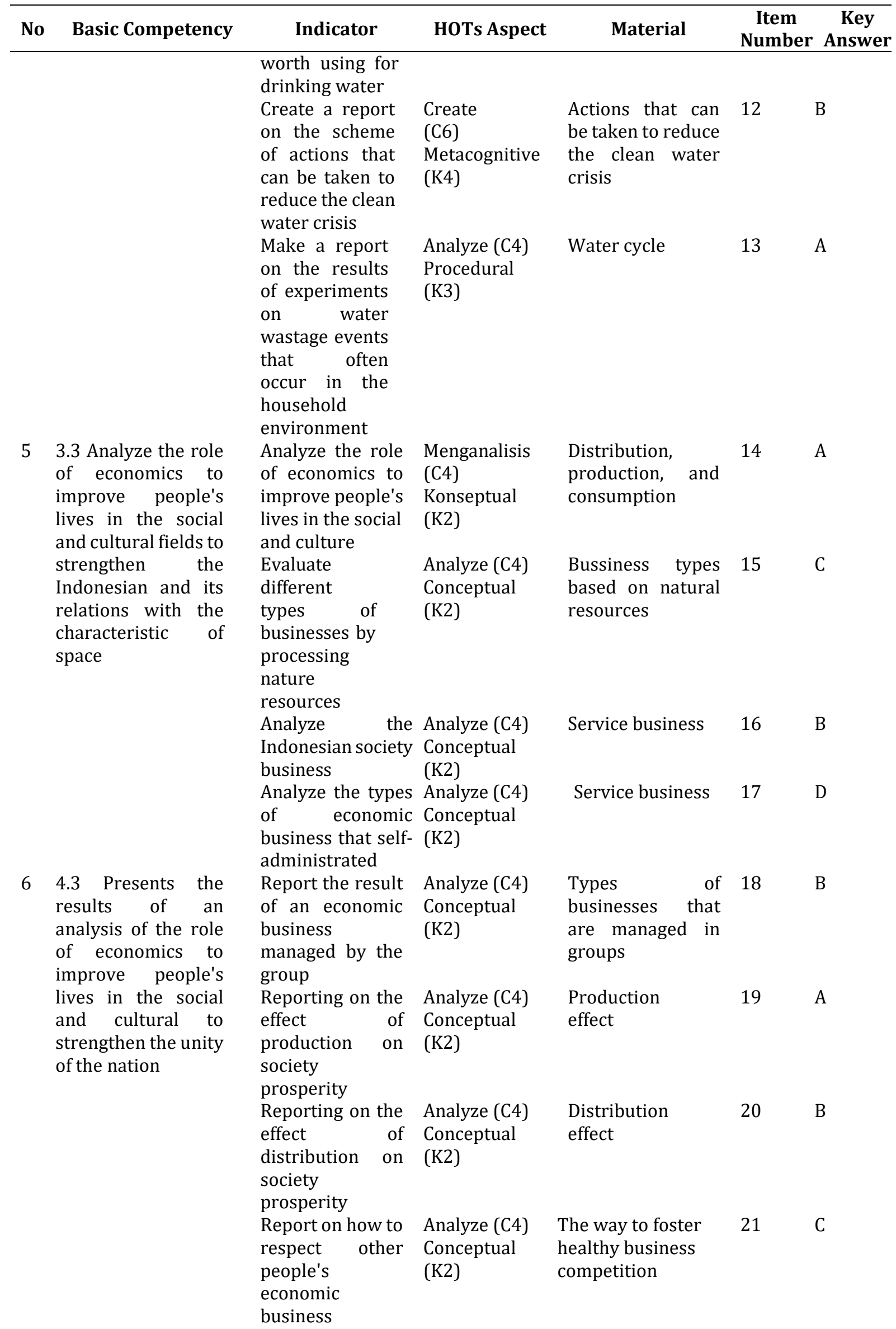




\begin{tabular}{|c|c|c|c|c|c|c|}
\hline No & Basic Competency & Indicator & HOTs Aspect & Material & $\begin{array}{c}\text { Item } \\
\text { Number }\end{array}$ & $\begin{array}{c}\text { Key } \\
r \text { Answer } \\
\end{array}$ \\
\hline \multirow{6}{*}{7} & \multirow{6}{*}{$\begin{array}{l}3.3 \text { Study the } \\
\text { socio-cultural } \\
\text { diversity of the } \\
\text { society }\end{array}$} & $\begin{array}{l}\text { Reporting on the } \\
\text { benefits of one } \\
\text { type of family } \\
\text { business }\end{array}$ & $\begin{array}{l}\text { Analyze (C4) } \\
\text { Conceptual } \\
(\mathrm{K} 2)\end{array}$ & $\begin{array}{l}\text { Type of family } \\
\text { business }\end{array}$ & 22 & A \\
\hline & & $\begin{array}{l}\text { Analyzing the } \\
\text { cultural diversity } \\
\text { of the Indonesian }\end{array}$ & $\begin{array}{l}\text { Analyze (C4) } \\
\text { Conceptual } \\
(\mathrm{K} 2)\end{array}$ & Custom House & 23 & $\mathrm{C}$ \\
\hline & & $\begin{array}{l}\text { Analyzing } \\
\text { the } \\
\text { diversity of } \\
\text { traditional } \\
\text { clothing }\end{array}$ & $\begin{array}{l}\text { Analyze (C4) } \\
\text { Conceptual } \\
(\mathrm{K} 2)\end{array}$ & Custom clothing & 24 & B \\
\hline & & $\begin{array}{l}\text { Analyzing the way } \\
\text { to conserve the } \\
\text { traditional game }\end{array}$ & $\begin{array}{l}\text { Analyze } \\
\text { (C4) }\end{array}$ & $\begin{array}{l}\text { The way to } \\
\text { conserve the } \\
\text { traditional game of }\end{array}$ & 25 & A \\
\hline & & & $\begin{array}{l}\text { Conceptual } \\
\text { (K2) }\end{array}$ & & & \\
\hline & & $\begin{array}{l}\text { Analyzing the } \\
\text { uniqueness of } \\
\text { villages in } \\
\text { Bali }\end{array}$ & $\begin{array}{l}\text { Analyze (C4) } \\
\text { Conceptual } \\
(\mathrm{K} 2)\end{array}$ & Trunyan Villa & 26 & $\mathrm{C}$ \\
\hline \multirow[t]{2}{*}{8} & $\begin{array}{l}4.3 \\
\text { Organizing activities } \\
\text { that support the socio- } \\
\text { cultural diversity of the } \\
\text { society }\end{array}$ & $\begin{array}{l}\text { Report on } \\
\text { activities that } \\
\text { support socio- } \\
\text { cultural } \\
\text { diversity of the } \\
\text { society }\end{array}$ & $\begin{array}{l}\text { Analyze (C4) } \\
\text { Metacognitive } \\
(\mathrm{K} 4)\end{array}$ & $\begin{array}{l}\text { Preserving } \\
\text { mutual respect }\end{array}$ & 27 & A \\
\hline & & $\begin{array}{l}\text { Reporting on } \\
\text { socio- } \\
\text { cultural } \\
\text { diversity } \\
\text { Of the community }\end{array}$ & $\begin{array}{l}\text { Analyze (C4) } \\
\text { Conceptual } \\
(\mathrm{K} 2)\end{array}$ & $\begin{array}{l}\text { Activities that } \\
\text { support the socio- } \\
\text { cultural diversity } \\
\text { of the society }\end{array}$ & 28 & $\mathrm{D}$ \\
\hline 9 & $\begin{array}{l}3.2 \text { Understand the } \\
\text { musical scale }\end{array}$ & $\begin{array}{l}\text { Analyze the } \\
\text { musical scale }\end{array}$ & $\begin{array}{l}\text { Analyze (C4) } \\
\text { Conceptual } \\
(\mathrm{K} 2)\end{array}$ & $\begin{array}{l}\text { Major diatonic } \\
\text { music scales }\end{array}$ & 29 & B \\
\hline 10 & $\begin{array}{l}3.3 \text { Understand } \\
\text { floor patterns in } \\
\text { traditional dance } \\
\text { creation }\end{array}$ & $\begin{array}{l}\text { Analyze the floor } \\
\text { patterns in } \\
\text { traditional } \\
\text { dance creation }\end{array}$ & $\begin{array}{l}\text { Analyze (C4) } \\
\text { Procedural } \\
\text { (K3) }\end{array}$ & $\begin{array}{l}\text { Triangular } \\
\text { patterns }\end{array}$ & 30 & $\mathrm{C}$ \\
\hline
\end{tabular}

The third stage in this investigation is the validation stage. At this stage, expert tests were conducted on four lecturers as judges to determine the feasibility of the HOTS instrument. After spreading the question to three elementary schools, this study conducted several data analysis tests: SD Negeri 1 Peninjoan, SD Negeri 5 peninjoan, and SD Negeri 6 Peninjoan. The data analysis in question is a test of the validity of the item, the reliability test, the level of validity test, the test of discriminatory power, the test of the effectiveness of the distractor. At the validation stage, expert tests were conducted on the initial product design tested by four experts/judges. Based on the assessment results using the formula CVR (Content Validity Ratio) obtained, a value of 1 to 30 questions was tested so that all intrusions are declared relevant. The results of the item validity test showed that overall the instrument was valid because the $r$-value was greater than the $r$-table value $=0.388$ at a significance level of $5 \%$ and the degree of freedom $=\mathrm{N}-2=26-$ $2=24$. Reliability test results showed a value of 0.93 . Good instruments at least have a high degree of reliability $0.60<r \leq 0.80$, so it can be concluded that the reliability of hots capability instruments tested has a very high degree of reliability. The results of the difficulty level test showed that the 30 points of the problem, seven problems were obtained, including the easy category, 21 questions included the medium category, and two problems included difficult categories.

Thus, the HOTS instruments tested had homogeneous difficulty standards in the simple to difficult categories. Next, a discriminatory power test is performed on the 30-point problem. The analysis results of 
30 points of the problem have a different power index of more than 0.40, which means that all HOTS instruments have an excellent discriminatory power index. Analysis of the effectiveness of the distractor was done by counting the participants who selected each alternative answer in each question item. A good distractor is when the distractor is selected by at least $5 \%$ of all participants. Considering the participants, 26 people, the distractor is good when selected by a minimum of $5 \%$ x $26=1.3=2$ people. The results showed that each HOTS ability-tested item had a good distractor.

\section{Discussion}

This research produces products using HOTS assessment instruments that have passed the item validity test stage, reliability test, difficulty level test, discrimination power test, and distractor effectiveness test. In the development process, the HOTS assessment instrument has adjusted to the characteristics of problems that meet the hots problem category and the procedure for developing categories about HOTS. The characteristics of the question must be fulfilled so that the question belongs to the category of HOTS, such as the curriculum used, the competence measured, the form of the problem developed, and others (Widhiyani et al., 2019; Wulandari et al., 2020). In this case, when compiling the HOTS question, the considered things include characteristics, indicators, and drafting steps (Widana, 2017). The product developed has been declared valid based on the results of the instrument validity test. By the validity, it can be stated that the developed instrument is declared feasible. Thus it can be ascertained that the instruments that have been made are worth using and indeed measure what is to be measured (Ernawati, 2017; Wagiran, 2013). Products developed have a very high degree of reliability. With very high reliability, it can be ascertained that the instrument developed will determine a test if tested on the same group even though it is done by different people (Arikunto, 2012; I. G. K. Widana et al., 2020). HOTS instruments developed have a homogeneous difficulty standard from easy to difficult. With a question that has a balanced level of difficulty, it can be stated that the question is good (Arifin, 2012; Ernawati, 2017). Each item about the HOTS skills instrument tested had a good distractor. Having a good distractor will make the problem can be used in distinguishing between high-skilled students and low-skilled students (Arikunto, 2012; Iskandar \& Rizal, 2018).

Overall, this study went well and produced high-quality products in the form of HOTS instruments. Making the HOTS question valid, reliable, and worth using must contain critical and creative thinking skills (Arifin \& Retnawati, 2017). Several previous studies support the findings of this study. The first study's results showed an influence of learning outcomes on students' thinking skills at the time of learning using the Higher Order Thinking Skill (HOTS) (Fazriani et al., 2019). Other research results showed that using HOTS-based students' worksheet books positively and significantly affects student learning motivation (Karsono, 2017). In addition, other research has resulted in HOTS questions that can significantly improve students' creative thinking skills compared to conventional exercises (Kamali, 2019). Other findings showed that higher-order thinking skills (HOTS) based math learning can improve the entrepreneurial spirit and student learning achievement (Muhyani et al., 2020). The research that has been done mentions a significant increase in students' high-level thinking skills after implementing LKPD-based mathematics learning based on HOTS (Purwasi \& Fitiyana, 2020). Other research states that higher-order thinking skills (HOTS) oriented scientific approaches on students' learning understanding (Putra \& Hanggara, 2018). The implication of this study is the result of a HOTS skills instrument for Grade V elementary students that teachers can use in learning assessments to obtain accurate results on cognitive aspects. HOTS skills instruments developed have been tested valid and reliable so that this instrument is worth using for learning assessment on cognitive aspects. Developing HOTS skills instruments on theme 8 (Our Friends' Environment) has never been implemented, so the resulting products are new. Many studies related to the development of instruments, but no one has yet developed HOTS ability instruments in students of grade V elementary school theme 8 (Our Friends' Environment). Therefore, the development of HOTS ability instruments is expected by teachers in learning assessment on cognitive aspects

\section{CONCLUSION}

Hots assessment instruments are developed to be of good quality based on analysis of validity, reliability, discrimination power, difficulty level, and effectiveness of the distractor. Therefore, it is suitable for learning assessment on the cognitive aspects of students.

\section{REFERENCES}

Amin, D. I., Sutrisno, \& Sigit, D. (2018). Instrumen Asesmen Pemahaman Konseptual Berorientasi Higher Order Thinking Skills Keterampilan Proses dan Sikap terhadap Sains pada Bahan Kajian 
Hidrokarbon dan Minyak Bumi. Jurnal Pendidikan: Teori, Penelitian, Dan Pengembangan, 3(9), 1142-1146. http://journal.um.ac.id/index.php/jptpp/.

Amirzan. (2017). Pengembangan Model Pembelajaran Gerak Dasar Lokomotor Pada Siswa SD Kelas V. Journal Physical Education, Health and Recreation, 2(1), 85. https://doi.org/10.24114/pjkr.v2i1.7843.

Anazalia, M., Darussyamsu, R., Lufri, L., Syamsurizal, S., \& Atifah, Y. (2021). Validitas Instrumen Tes Berpikir Tingkat Tinggi (Hots) Tentang Materi Sistem Pencernaan Untuk Peserta Didik Kelas Xi Sma/Ma. BIOTIK: Jurnal Ilmiah Biologi Teknologi Dan Kependidikan, 8(2), 232. https: //doi.org/10.22373/biotik.v8i2.7090.

Arifin, Z. (2012). Evaluasi Pembelajaran. Rosda Karya.

Arifin, Z., \& Retnawati, H. (2017). Pengembangan instrumen pengukur higher order thinking skills matematika siswa SMA kelas X. Pythagoras: Jurnal Pendidikan Matematika, 12(1), 98-108. https://doi.org/10.21831/pg.v12i1.14058.

Arikunto, S. (2012). Dasar-dasar Evaluasi Pendidikan. Bumi Aksara.

Aviory, K., \& Susetyawati, M. E. (2021). Kualitas Soal Hots (High Order Thinking Skill) Pada Siswa Smp Kelas Vii. AKSIOMA: Jurnal Program Studi Pendidikan Matematika, 10(2), 639. https: //doi.org/10.24127/ajpm.v10i2.3087.

Cayani, S., Lubis, M., \& Saltifa, P. (2021). Pengembangan Soal Higher Order Thinking Skill (Hots) Materi Bilangan Di Sekolah Menengah Pertama. Supermat (Jurnal Pendidikan Matematika), 4(2), 32-44. https://doi.org/10.33627/sm.v4i2.467.

Ernawati, I. (2017). Uji Kelayakan Media Pembelajaran Interaktif Pada Mata Pelajaran Administrasi Server. Elinvo (Electronics, Informatics, and Vocational Education), 2(2), 204-210. https://doi.org/10.21831/elinvo.v2i2.17315.

Fazriani, N., Supendi, D. A., \& Humaira, H. W. (2019). Pengaruh Pendekatan Higher Order Thinking Skill (Hots) Terhadap Keterampilan Membaca Siswa Kelas X SMK Negeri 3 Kota Sukabumi. Stilistika: $\begin{array}{lllll}\text { Jurnal Pendidikan } & \text { Bahasa } & \text { 124-138. }\end{array}$ https://doi.org/http://dx.doi.org/10.30651/st.v12i2.2802.

Granberg, C., Palm, T., \& Palmberg, B. (2021). A case study of a formative assessment practice and the effects on students' self-regulated learning. Studies in Educational Evaluation, 68(August 2020). https: //doi.org/10.1016/j.stueduc.2020.100955.

Iskandar, A., \& Rizal, M. (2018). Analisis kualitas soal di perguruan tinggi berbasis aplikasi TAP. Jurnal Penelitian Dan Evaluasi Pendidikan, 22(1), 12-23. https: //doi.org/10.21831/pep.v22i1.15609.

Kamali, A. S. (2019). Pengaruh Soal Tipe HotsTerhadap Kemampuan Berfikir Kreatif Siswa. Cakrawala Pedagogi, 3(2), 128-131. https://doi.org/https://doi.org/10.51499/cp.v3i2.110.

Karsono. (2017). pengaruh penggunaan LKS Berbasis HOTS terhadap Motivasi dan Hasil Belajar IPA Siswa SMP. Jurnal Pendidikan Matematika Dan Sains, 1, 50-57. https://doi.org/10.21831/jpms.v5i1.13540.

Msosa, A., Bruce, J., \& Crouch, R. (2021). Effect of a formative assessment intervention on nursing skills laboratory learning in a resource-constrained country. Nurse Education Today, 97(October 2019), 104677. https://doi.org/10.1016/j.nedt.2020.104677.

Muhyani, Nafisah, I. D., \& Sutisna. (2020). Melejitkan Jiwa Kewirausahaan Dan Prestasi Belajar Melalui Pembelajaran Matematika Berbasis Higher Order Thinking Skills (HOTS). Aksioma : Jurnal Program $\begin{array}{llll}\text { Studi } \quad \text { Pendidikan } & \text { Matematika, 936-949. }\end{array}$ https://doi.org/https://doi.org/10.24127/ajpm.v9i4.3159.

Ndiung, S., \& Jediut, M. (2020). Pengembangan instrumen tes hasil belajar matematika peserta didik sekolah dasar berorientasi pada berpikir tingkat tinggi. Premiere Educandum: Jurnal Pendidikan Dasar Dan Pembelajaran, 10(1), 94-111. https://doi.org/10.25273/pe.v10i1.6274.

Noprinda, C. T., \& Soleh, S. M. (2019). Development Of Student Worksheet Based On Higher Order Thinking Skill (Hots ). Indonesian Journal of Science and Mathematics Education, 02(2), 168-176. https://doi.org/10.24042/IJSME.V2I2.4342.

Prayitno, B. A. (2018). Enhancing Students Higher Order Thinking Skills in Science Through Instad Strategy. Journal of Baltic Science Education, 17(6), 1046-1055.

Purwasi, K. A., \& Fitiyana, N. (2020). Peningkatan Kemampuan Berpikir Tingkat Tinggi Siswa Melalui Pembelajaran Matematika Berbantuan LKPD Berbasis HOTS. Jurnal Pendidikan Matematika: Judika Education, 3(2), 65-74. https://doi.org/https://doi.org/10.31539/judika.v3i2.1594.

Putra, R. A., \& Hanggara, A. (2018). Pengaruh Pendekatan Pembelajaran Saintifik Berorientasi Higher Order Thinking Skills ( HOTS ). Equilibrium: Jurnal Penelitian Pendidikan Dan Ekonomi, 15(2), 44-50. https://doi.org/10.25134/equi.v15i02.Abstract.

Safitri, K., \& Harjono, N. (2021). Pengembangan Instrumen Penilaian Sikap Sosial Aspek Tanggung Jawab 
Pembelajaran Tematik Terpadu Siswa Kelas 4 SD. Jurnal Pedagogi Dan Pembelajaran, 4(1), 111. https://doi.org/10.23887/jp2.v4i1.33352.

Sani, R. A. (2016). Penilaian Autentik. Bumi Aksara.

Schildkamp, K., van der Kleij, F. M., Heitink, M. C., Kippers, W. B., \& Veldkamp, B. P. (2020). Formative assessment: A systematic review of critical teacher prerequisites for classroom practice. International Journal of Educational Research, 103(April), 101602. https://doi.org/10.1016/j.ijer.2020.101602.

Solihah, A. N., Jubaedah, Y., \& Rifa'i, M. S. S. (2020). Pengembangan Instrumen Pengukuran Perkembangan Sosial-Emosional Anak Berbasis Home-Based Childcare. Widyadari, 6(1). https://doi.org/https://doi.org/10.5281/zenodo.3517997.

Sugian Noor. (2020). Penggunaan Quizizz Dalam Penilaian Pembelajaran Pada Materi Ruang Lingkup Biologi Untuk Meningkatkan Hasil Belajar Siswa Kelas X.6 SMA 7 Banjarmasin. Jurnal Pendidikan Hayati, 6(1), 1-7. https://doi.org/https://doi.org/10.33654/jph.v1i1.927.

Tridane, M., Belaaouad, S., Benmokhtar, S., Gourja, B., \& Radid, M. (2015). The Impact of Formative Assessment on the Learning Process and the Unreliability of the Mark for the Summative Evaluation. Procedia - Social and Behavioral Sciences, 197(February), 680-685. https://doi.org/10.1016/j.sbspro.2015.07.058.

Umami, R., Rusdi, M., \& Kamid, K. (2021). Pengembangan Instrumen Tes Untuk Mengukur Higher Order Thinking Skills (Hots) Berorientasi Programme For International Student Asessment (Pisa) Pada Peserta Didik. JP3M: Jurnal Penelitian Pendidikan Dan Pengajaran Matematika, 7(1). https://doi.org/10.37058/jp3m.v7i1.2069.

Wagiran. (2013). Metodelogi Penelitian Pendidikan. CV. Budi Utama.

Widana, I. G. K., Dantes, N., \& Parmiti, D. P. (2020). Pengembangan Perangkat Pembelajaran Matematika Materi Pengolahan Data Berbasis Pendekatan PMRI. Jurnal Ilmiah Pendidikan Profesi Guru, 3(3), 477. https://doi.org/10.23887/jippg.v3i3.29428.

Widana, I. W. (2017). Modul Penyusunan Higher Order Thinking Skills (HOTS). Direktorat Pembinaan SMA, Direktorat Jenderal Pendidikan Dasar dan Menengah,Department Pendidikan dan Kebudayaan.

Widhiyani, I. A. N. T., Sukajaya, I. N., \& Suweken, G. (2019). Pengembangan Soal Higher Order Thinking Skills Untuk Pengkategorian Kemampuan Pemecahan Masalah Geometri Siswa Smp. Jurnal Pendidikan Dan Pembelajaran Matematika Indonesia, 8(2), 68-77. https://doi.org/10.23887/jppm.v8i2.2854.

Wulandari, S., Hajidin, H., \& Duskri, M. (2020). Pengembangan Soal Higher Order Thinking Skills (HOTS) pada Materi Aljabar di Sekolah Menengah Pertama. Jurnal Didaktik Matematika, 7(2), 200-220. https://doi.org/10.24815/jdm.v7i2.17774.

Xiao, Y., \& Yang, M. (2019). Formative assessment and self-regulated learning: How formative assessment supports students' self-regulation in English language learning. System, 81, 39-49. https://doi.org/10.1016/j.system.2019.01.004.

Yugakisha, M. S., \& Jayanta, I. N. L. (2021). Instrumen Penilaian Motivasi Belajar IPA. Jurnal Pedagogi Dan Pembelajaran, 4(3), 402. https: //doi.org/10.23887/jp2.v4i2.35918.

Yusup, F. (2018). Uji Validitas dan Reliabilitas Instrumen Penelitian Kuantitatif. Jurnal Tarbiyah : Jurnal Ilmiah Kependidikan, 7(1), 17-23. https://doi.org/10.18592/tarbiyah.v7i1.2100.

Zhang, X. (2020). Assessment for learning in constrained contexts: How does the teacher's self-directed development play out? Studies in Educational Evaluation, 66(November 2019), 100909. https://doi.org/10.1016/j.stueduc.2020.100909. 